報告

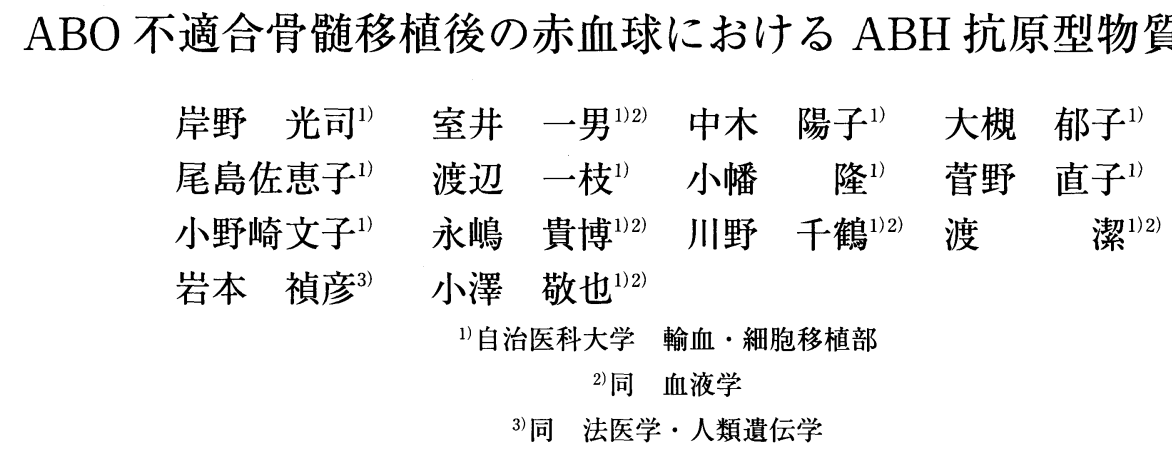

(平成13年 1 月 12 日受付)

(平成14年 3 月13日受理)

\title{
ANALYSIS OF ABH ANTIGENS IN ERYTHROCYTES AFTER ABO-INCOMPATIBLE BONE MARROW TRANSPLANTATION
}

\author{
Koji Kishino ${ }^{1)}$, Kazuo Muroi ${ }^{12)}$, Yoko Nakaki ${ }^{11}$, Ikuko Otuki ${ }^{11}$, Saeko Ojima ${ }^{1)}$, \\ Kazue Watanabe ${ }^{1)}$, Takashi Obata ${ }^{1)}$, Naoko Sugano, ${ }^{1)}$, Fumiko Onozaki ${ }^{1)}$, \\ Takahiro Nagashima ${ }^{12)}$, Chizuru Kawano ${ }^{12)}$, Kiyoshi Watari ${ }^{122}$, \\ Sadahiko Iwamoto ${ }^{3)}$ and Keiya Ozawa ${ }^{122}$ \\ ${ }^{1)}$ Division of Cell Transplantation and Transfusion, ${ }^{2}$ Division of Hematology, Department of Medicine, \\ ${ }^{3}$ Department of Legal Medicine and Human Genetics, Jichi Medical School
}

$\mathrm{ABH}$-antigens and A-and B-glycosyltransferase activity were examined in four patients who received an ABO-incompatible bone marrow transplant from HLA-matched donors. ABO phenotype and $\mathrm{ABO}$ genotype were analyzed using flow cytometry and polymerase chain reaction with sequence specific reaction, respectively. On day 14 after bone marrow transplantation (BMT), the ABO genotype of erythroid burst-forming units was converted into the $\mathrm{ABO}$ genotype of the donors in all of the recipients. Afterward, $A B O$ phenotype of red blood cells . $\mathrm{RBC}$ ) in all recipients completely changed to that of the donors. Rh, P, Diego, Kidd, Duffy and MNSs phenotypes were also changed into the donor's phenotypes. However, in one patient the Lewis blood type did not change into the donor's phenotype. Similarly, using an elution method, $\mathrm{ABH}$ antigens of the recipients were detected in $\mathrm{RBC}$ in all of the recipients after BMT. In two recipients, the serum glycosyltransferase activities of the recipients were only detected after $\mathrm{BMT}$. These findings indicate that $\mathrm{ABH}$ antigens may be released from non-blood cells and adsorbed by $\mathrm{RBC}$, although the possibility of $\mathrm{ABO}$ chimeras or unknown mechanisms is not ruled out. Further studies are needed to determine the nature of $\mathrm{ABH}$ antigens eluted from $\mathrm{RBC}$ of recipients receiving an $\mathrm{ABO}$-incompatible bone marrow transplant.

Key words : Bone Marrow Transplantation, $\mathrm{ABO}$-incompatibility, $\mathrm{ABH}$ antigens, $\mathrm{ABO}$ genotype, ABO phenotype

\section{序言}

ヒト血液型の $\mathrm{A}, \mathrm{B}$ 抗原の合成は, $\mathrm{H}$ 物質に $\alpha$
1-3N-acetylgalactosaminyltransferase（A 型糖転 移酵素）が作用し, N-acetylgalactosamine（Gal- 
NAc）を $\alpha 1 \rightarrow 3$ 結合すると A 型抗原になり， $\alpha 1-$ 3galactosyltransferase (B 型糖転移酵素)の作用に より galactose $(\mathrm{Gal})$ が $\alpha 1 \rightarrow 3$ 結合して $\mathrm{B}$ 型抗原 となる. 1990 年, Yamamoto らによって ABO 血液型糖転移酵素の $\mathrm{cDNA}$ 塩基配列が決定され た ${ }^{122}$. A 遺伝子と B 遺伝子の差は，タンパク質の コーディング領域内の 7 力所の塩基置換と 4 力所 のアミノ酸置換であることが明らかにされた。一 方, $\mathrm{O}$ 遺伝子は $\mathrm{A}$ 遺伝子の一つの塩基欠失が示さ れた。これらの遺伝子の多形性を利用して, $\mathrm{ABO}$ 血液型の遺伝子診断が行われている3 ${ }^{31}$.

ABO 血液型不適合同種骨䯣移植 $(\mathrm{BMT})$ におい て, BMT レシピエントの ABO 血液型抗原の推移 をフローサイトメトリー等を用いて検討した報告

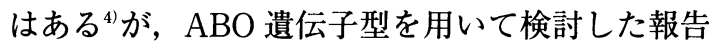
は少ない. 今回, 私達は $\mathrm{ABO}$ 血液型不適合 $\mathrm{BMT}$ を受けたレシピエントにおいて，末梢血単核細胞 または赤芽球バーストの $\mathrm{ABO}$ 遺伝子型，赤血球 表面上の $\mathrm{ABH}$ 血液型物質の存在, 血清中の糖転 移酵素活性, $\mathrm{ABO}$ 式血液型以外の血液型変化を検 討したので報告する。

\section{対象および方法}

\section{対象}

1998 年 10 月から 1999 年 10 月，当院血液科で ABO 血液型不適合 BMT を受け, 長期観察可能で 経過中再発がなかった 4 例を対象とした（Table 1).メジャー ABO 不適合 BMT3 例とマイナー $\mathrm{ABO}$ 不適合 BMT1 例.

\section{方法}

\section{1. コロニー}

末梢血から Ficoll-Hypaque (Lymphoprep ; Nycomed Pharma）を用い比重遠心法によって単核 細胞（MNC）を分離した. $1 \times 10^{5}$ 個の MNCを 30 $\%$ 牛胎児血清, $1 \%$ 牛アルブミン, $3 \mathrm{U}$ rh Erythropoietin, $10^{-4} \mathrm{M}$ 2-Mercaptoethanol, 2mM L-glutamine, 50ng rh Stem Cell Factor, 10ng rh GMCSF, 10ng rh IL-3 を含む 1ml のメチルセルロー 又培地 (MethoCult GF H4434 ; StemCell Technologies Inc.) に浮遊させ, $5 \% \mathrm{CO}_{2}, 37^{\circ} \mathrm{C}$ の条件下で 14 日間培養した．倒立顕微鏡下に，ピペットを用 いて形成された赤芽球バースト（BFU-E）を測定
日当たり約 5 個吊り上げ，1 本のマイクロチュー ブに混和し $-80^{\circ} \mathrm{C}$ で保存した。

\section{Flow cytometry (FCM)}

赤血球をグルタールアルデヒド固定し，抗 $\mathrm{A}$ および抗 B モノクローナル抗体 (Ortho Diagnostic Systems Inc.）と $4^{\circ} \mathrm{C} 30$ 分 反応後, PBS で 2 回洗浄した. 抗ヒト Immunoglobulin を加え $4^{\circ} \mathrm{C}$ 30 分反応後, PBS で 2 回洗浄L, FCM (Cytoron； Ortho Diagnostic Systems）を用いて A 抗原陽性 および B 抗原陽性の赤血球を測定した。

\section{A および B 糖転移酵素活性の測定}

測定用試薬 (ガルサーブ $\mathrm{AB}$ ；三光純薬）を用い て,血清中の $\mathrm{A}$ および $\mathrm{B}$ 糖転移酵素活性を測定し た. 血清をUDP-GalNAc あるいはUDP-Gal の存 在下で，新鮮な $\mathrm{O}$ 型赤血球と混和した．血清中の $\mathrm{A}$ または $\mathrm{B}$ 糖転移酵素によって, 赤血球表面に形 成された $\mathrm{A}$ 型抗原または $\mathrm{B}$ 型抗原の抗 $\mathrm{A}$ および 抗 B 抗体の被凝集価を求め，それぞれ $\mathrm{A}, \mathrm{B}$ 糖転 移酵素活性の力価とした5).

\section{PCR-SSP (Polymerase Chain Reaction} With Sequence Specific Primers)

末梢血 MNC または赤芽球バーストからグアニ ジン法を用いて DNA を抽出した。高分子 DNA をテンプレートとし， A 型，B 型および $\mathrm{O}$ 型にお いて塩基配列の異なった部位にプライマーを設定 し, PCR を行った. 福森らの方法 ${ }^{6}$ に従ってプライ マーの組み合わせは，GA23-GA13(B)，GA23-GA 14 (A)，GA24-GA14（O)の 3 組で行い，それぞ れで $\mathrm{B}, \mathrm{A}, \mathrm{O}$ 遺伝子を別々にアリル特異的に増幅 し，増幅断片の有無で $\mathrm{ABO}$ 遺伝子型を判定した。 PCR の条件は，以下のごとく改変した. 最終濃度 $0.4 \mu \mathrm{M}$ primers, $50 \mathrm{mM} \mathrm{KCl}, 1.5 \mathrm{mM} \mathrm{MgCl}_{2}, 10$ $\mathrm{mM}$ Tris- $\mathrm{HCl}(\mathrm{pH} 8.3), 0.01 \% \mathrm{w} /$ vgelatin, $0.2 \mathrm{mM}$ 各 $\operatorname{dNTP}$ (dATP, dCTP, dGTP, and dTTP), のバッファー中に0.4 U Taq DNA polymerase (AmpliTaq ; Perkin Elmer)， 100 300ngDNA, を加え $10 \mu l$ とした. 増幅条件は, denaturation 94 ${ }^{\circ} \mathrm{C} 1$ 分, anealing $63^{\circ} \mathrm{C} 1$ 分, extension $72^{\circ} \mathrm{C} 1$ 分で 30 cycles とし, thermal cycler (GeneAmp PCR System 9600 ; Perkin Elmer)，を用いて施行し た. PCR 産物は $2.0 \%$ アガロースゲル電気泳動後 
Table 1 Characteristics of recipients and donors

\begin{tabular}{|c|c|c|c|c|c|c|c|c|c|}
\hline \multirow{2}{*}{ No. } & \multicolumn{6}{|c|}{ Recipient } & \multicolumn{3}{|c|}{ Donor } \\
\hline & Age & Sex & Disease & Conditioning & Infused cells $\left(\times 10^{7} / \mathrm{kg}\right)$ & ABO genotype & Age & Sex & ABO genotype \\
\hline 1 & 21 & $\mathrm{M}$ & ALL & TBL/VP16/CY & $5.03^{*}$ & $\mathrm{BO}$ & 22 & $\mathrm{~F}$ & $\mathrm{AO}$ \\
\hline 2 & 26 & M & CML & $\mathrm{TBI} / \mathrm{CA} / \mathrm{CY}$ & $50.49^{\Uparrow}$ & $\mathrm{AO}$ & 41 & M & $\mathrm{OO}$ \\
\hline 3 & 18 & M & LBL & TBI/VP16/CY & $6.13 \%$ & $\mathrm{BO}$ & 25 & $\mathrm{~F}$ & $\mathrm{AO}$ \\
\hline 4 & 22 & M & CML & $\mathrm{TBI} / \mathrm{CA} / \mathrm{CY}$ & $6.73 *$ & BO & 22 & M & AA \\
\hline
\end{tabular}

* , mononuclear cells; ^ , nucleated cells; ALL, acute lymphoblastic leukemia; CML, chronic myelogeneous leukemia; LBL, lymphoblastic lymphoma; TBI, total body irradiation; VP16, etoposide; CA, cytarabine; CY, cyclophosphamide.

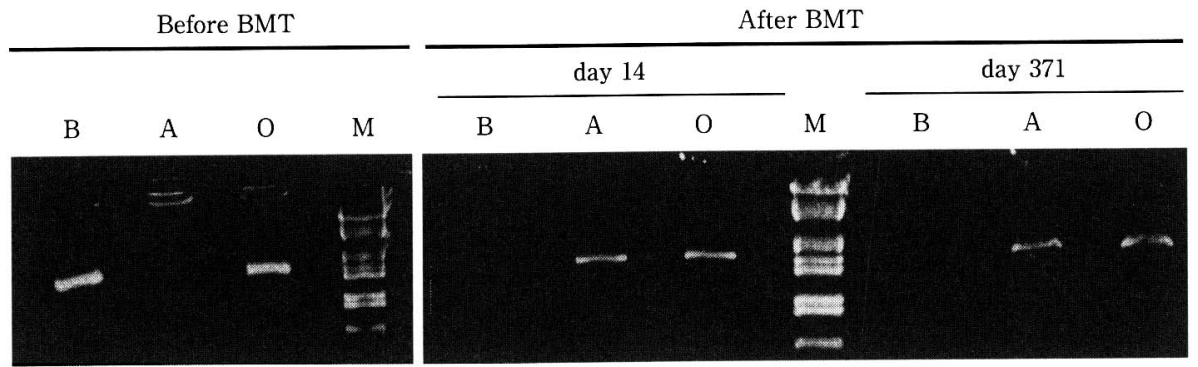

Fig. 1 ABO group genotyping of a patient (No. 3) by the PCR-SSP method. Before BMT, the ABO genotype of MNC was BO. After BMT, the ABO genotype of $\mathrm{BFU}-\mathrm{E}$ on day 14 and that of MNC on day 371 were converted to AO. M, molecular weight maker.

エチジウムブロマイド染色し，UV照射により検 出した。

\section{5. $\mathbf{A B O}$ 式血液型以外の血液型検査}

BMT 前のレシピエントおよびドナー赤血球の $\mathrm{ABO}$ 以外の血液型抗原 (Rh, Diego, MNSs, P, Duffy，Kidd，Lewis 式血液型)を市販抗体試薬を 用い，試験管法にて反応させ凝集の有無にて判定 した.また BMT 後, 長期間経過したレシピエント 赤血球を同様な方法にて検討した.

\section{6. 抗体吸着解離試験}

赤血球表面の $\mathrm{ABH}$ 血液型物質の存在を，抗体

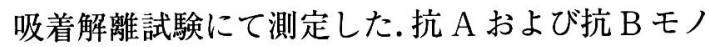
クローナル抗体 (Ortho) をレシピエント赤血球と 陰性対照である健常人の $\mathrm{O}$ 型赤血球に，1昼夜 4 ${ }^{\circ} \mathrm{C}$ にて吸着反応させ, Landsteiner \& Miller 法 ${ }^{7} の$ 熱解離を行った。解離温度条件は，モノクローナ ル抗体ではポリクローナル抗体に比べ加熱操作に よる影響を受け易いため， $52^{\circ} \mathrm{C} ， 10$ 分間抗体を定 期的に振とうし解離した。解離した抗体の存在は,
$\mathrm{ABO}$ 血球に対する反応を食塩水法を用いて測定 した.

\section{結 果}

1) BMT 14 日後, レシピエント 4 症例で BFU$\mathrm{E}$ の $\mathrm{ABO}$ 遺伝子型をPCR-SSP 法を用いて測定 した. 4 症例すべてにおいて, BFU-Eの ABO 遺伝 子型はドナーの $\mathrm{ABO}$ 遺伝子型に変換していた (Table 2, Fig. 1).また, 4 症例の長期観察におい ても，末梢血 MNCの $\mathrm{ABO}$ 遺伝子型は, ドナーの $\mathrm{ABO}$ 遺伝子型に変換されていることが確認でき た (Table 2, Fig. 1).

2） BMT 後, レシピエント ABO 血液型が完全 にドナー型に変換したのを FCM を用いて確認 後, $\mathrm{ABO}$ 血液型以外の血液型抗原を検査した $(\mathrm{Ta}-$ ble 3). 4 症例とも Rh 式血液型はドナー型に変換 していた. MNSs と P 式血液型（症例 2), Duffy と Kidd 式血液型 (症例 3), Diego 式血液型 (症例 1,3）もドナー型に変化していた. 一方, Lewis 式血液型が検查された(症例 4) では, BMT 後 126 
Table 2 Genotypic analysis of ABO blood group antigens after BMT

\begin{tabular}{|c|c|c|c|c|c|c|}
\hline \multirow{2}{*}{ No. } & \multirow{2}{*}{ DNA } & \multirow{2}{*}{$\begin{array}{l}\text { Days after } \\
\text { BMT }\end{array}$} & \multicolumn{3}{|c|}{ ABO primers } & \multirow{2}{*}{$\begin{array}{c}\mathrm{ABO} \\
\text { genotype }\end{array}$} \\
\hline & & & GA23-GA13(B) & GA23-GA14(A) & GA24-GA14(O) & \\
\hline \multirow{2}{*}{1} & BFU-E & 14 & - & + & + & \multirow{2}{*}{$\mathrm{AO}$} \\
\hline & MNC & 188 & - & + & + & \\
\hline \multirow{2}{*}{2} & BFU-E & 14 & - & - & + & \multirow{2}{*}{$\mathrm{OO}$} \\
\hline & MNC & 83 & - & - & + & \\
\hline \multirow{2}{*}{3} & BFU-E & 14 & - & + & + & \multirow{2}{*}{$\mathrm{AO}$} \\
\hline & MNC & 371 & - & + & + & \\
\hline \multirow{2}{*}{4} & BFU-E & 14 & - & + & - & \multirow{2}{*}{$\mathrm{AA}$} \\
\hline & $\mathrm{MNC}$ & 166 & - & + & - & \\
\hline
\end{tabular}

Table 3 Red blood cell antigens excluding ABO antigens

\begin{tabular}{|c|c|c|c|c|c|c|c|c|}
\hline \multirow{2}{*}{ No. } & & \multirow{2}{*}{\multicolumn{3}{|c|}{$\frac{\text { Before BMT }}{\text { Red cell antigens }}$}} & \multicolumn{4}{|c|}{ After BMT } \\
\hline & & & & & \multicolumn{3}{|c|}{ Red cell antigens } & Days after BMT \\
\hline \multirow{2}{*}{1} & Recipient & \multicolumn{3}{|c|}{$\operatorname{Dia}(-)$} & CCDee & $\operatorname{Dia}(+)$ & & $15 \dot{3}$ \\
\hline & Donor & CCDee & $\operatorname{Dia}(+)$ & & & & & \\
\hline \multirow{2}{*}{2} & Recipient & CcDee & MsNs & $\mathrm{P} 1(-)$ & CCDee & MSMs & $\mathrm{P} 1(+)$ & 356 \\
\hline & Donor & CCDee & MSMs & $\mathrm{P} 1(+)$ & & & & \\
\hline \multirow{2}{*}{3} & Recipient & CCDee & $\operatorname{Dia}(+)$ & $\begin{array}{l}\text { Fy }(a+b+) \\
\mathrm{Jk}(a-b+)\end{array}$ & $\mathrm{CcDEe}$ & $\operatorname{Dia}(-)$ & $\begin{array}{l}\text { Fy }(a+b-) \\
\operatorname{Jk}(a+b+)\end{array}$ & 371 \\
\hline & Donor & $\mathrm{CcDEe}$ & $\operatorname{Dia}(-)$ & $\begin{array}{l}\text { Fy }(a+b-) \\
\operatorname{Jk}(a+b+)\end{array}$ & & & & \\
\hline \multirow{2}{*}{4} & Recipient & $\mathrm{CcDEe}$ & \multicolumn{2}{|c|}{$\operatorname{Le}(a-b+)$} & CCDee & \multicolumn{2}{|c|}{$\operatorname{Le}(a-b+)$} & 166 \\
\hline & Donor & CCDee & \multicolumn{2}{|c|}{$\operatorname{Le}(a+b-)$} & & & & \\
\hline
\end{tabular}

日と 166 日においても BMT 前のレシピエント型 が示され，ドナー型に変換することはなかった。

3） BMT 後 97 日から 371 日にかけて，レシピ エントの赤血球表面上の $\mathrm{ABH}$ 血液型物質の存在 を感度の高い抗体吸着解離試験を用いて測定した (Table 4).メジャーABO 不適合 BMT 3 例 (症例 1,97 日より 188 日; 症例 3,238 日より 371 日; 症例 4, 126 日より 166 日）とマイナー $\mathrm{ABO}$ 不適 合 BMT1 例 (症例 2,97 日より 356 日) でどの観察 時点においても解離液中に抗体の存在が確認され た.すなわち, 4 症例とも BMT 前のレシピエント 型の $\mathrm{ABH}$ 血液型物質の存在が示唆された. また, FCM を用いて, ABO 血液型は完全にドナー型に 変換したのを確認した（Table 4).
4）レシピエント血清中の $\mathrm{A}$ および $\mathrm{B}$ 糖転移酵 素活性を, BMT 後経時的に測定した (Table 4). 症例 1 と 2 は, BMT 後もレシピエント型の糖転 移酵素活性を示した. しかし, 症例 2 については, 97 日，132 日に 128 倍と BMT の経過に伴いレシ ピエント型の酵素活性を示したが，356日におい ては活性反応が消失した. 症例 3 と 4 は, BMT 後ドナー型とレシピエント型の両方の糖転移酵素 活性を示した。

\section{考察}

4 症例において, BMT を受けてから長期間経過 後, ABO, Rh, MNSs, P, Duffy, Kidd, Diego 式血液型はドナー型に変化していた。しかし，ド ナーとレシピエントの Lewis 式血液型が異なっ 
Table 4 Analysis of ABO antigens on red blood cells after BMT

\begin{tabular}{|c|c|c|c|c|c|c|c|}
\hline \multirow{2}{*}{ No. } & \multirow{2}{*}{$\begin{array}{c}\text { Days after } \\
\text { BMT }\end{array}$} & \multicolumn{2}{|c|}{ FCM method } & \multicolumn{2}{|c|}{ Tansferase activiity } & \multirow{2}{*}{$\begin{array}{l}\text { Secretion } \\
\text { type }\end{array}$} & \multirow{2}{*}{$\begin{array}{l}\text { Elution } \\
\text { method }\end{array}$} \\
\hline & & $\mathrm{A} \%$ & $\mathrm{~B} \%$ & A transferase (Cont.) & B transferase (Cont.) & & \\
\hline 1 & $\begin{array}{r}97 \\
111 \\
139 \\
153 \\
188\end{array}$ & $\begin{array}{l}96.3 \\
97.8 \\
98.9 \\
98.7 \\
99.4 \\
\end{array}$ & $\begin{array}{l}0.1 \\
0.0 \\
0.1 \\
0.9 \\
0.1 \\
\end{array}$ & $\begin{array}{ll}0 & (\times 128) \\
0 & (\times 128) \\
0 & (\times 256) \\
0 & (\times 128) \\
0 & (\times 64)\end{array}$ & $\begin{array}{ll}\times 16 & (\times 64) \\
\times 32 & (\times 128) \\
\times 32 & (\times 128) \\
\times 32 & (\times 64) \\
\times 32 & (\times 32) \\
\end{array}$ & secretor & $\begin{array}{l}\mathrm{B} \\
\mathrm{B} \\
\mathrm{B} \\
\mathrm{B} \\
\mathrm{B}\end{array}$ \\
\hline 2 & $\begin{array}{r}97 \\
132 \\
356 \\
\end{array}$ & $\begin{array}{l}1.6 \\
0.4 \\
0.3 \\
\end{array}$ & $\begin{array}{l}0.6 \\
0.3 \\
0.3 \\
\end{array}$ & $\begin{array}{r}\times 128(\times 128) \\
\times 128(\times 128) \\
0(\times 128)\end{array}$ & $\begin{array}{ll}0 & (\times 64) \\
0 & (\times 64) \\
0 & (\times 128)\end{array}$ & secretor & $\begin{array}{l}\mathrm{A} \\
\mathrm{A} \\
\mathrm{A}\end{array}$ \\
\hline 3 & $\begin{array}{l}238 \\
371 \\
\end{array}$ & $\begin{array}{l}98.9 \\
\text { NT }\end{array}$ & $\begin{array}{l}0.4 \\
\text { NT }\end{array}$ & $\begin{array}{r}\times 8(\times 64) \\
\times 16(\times 128)\end{array}$ & $\begin{array}{l}\times 16(\times 128) \\
\times 32(\times \quad 64) \\
\end{array}$ & secretor & $\begin{array}{l}\mathrm{B} \\
\mathrm{B}\end{array}$ \\
\hline 4 & $\begin{array}{l}126 \\
138 \\
166\end{array}$ & $\begin{array}{l}\text { NT } \\
98.6 \\
99.4\end{array}$ & $\begin{array}{l}\text { NT } \\
0.3 \\
0.1\end{array}$ & $\begin{array}{l}\text { NT } \\
\times 16(\times 128) \\
\times 64 \quad(\times 256)\end{array}$ & $\begin{array}{l}\text { NT } \\
\times 32(\times 128) \\
\times 32 \quad(\times 128)\end{array}$ & secretor & $\begin{array}{l}\mathrm{B} \\
\mathrm{B} \\
\mathrm{B}\end{array}$ \\
\hline
\end{tabular}

NT, not tested

た症例 4 では, BMT 後もドナー型に変換せず, BMT 前のレシピエント型の Lewis 式血液型を継 続的に呈した. Lewis 式血液型抗原の生合成は, Le 遺伝子が産生する $\alpha 1-4 f u c o s y l t r a n s f e r a s e （ \alpha 1-$ 4Fuc-T）によって H1 型前駆物質の糖鎖末端より 2 番目の N-acetylglucosamine（GlcNAc）に L-fucose が結合し, Le $\mathrm{e}^{\mathrm{a}}$ 抗原が合成される. 分泌型 (secretor）の場合 $\alpha 1$-2fucosyltransferase（ $\alpha 1$-2FucT）によって, Se 遺伝子の支配下で産生された H 1 型物質（Fuc $\alpha 1-2 \mathrm{Gal} \beta 1-3 \mathrm{GlcNAc} \beta 1-\mathrm{R}$ ) に, $\alpha 1-4$ Fuc-Tによって L-fucose が結合し, Le ${ }^{\mathrm{b}}$ 抗原が合 成される ${ }^{899)}$. Le 遺伝子と Se 遺伝子の両者が Lewis 抗原の発現に関与している ${ }^{810)}$.このように, Lewis 式血液型抗原は赤血球で産生されるのでは なく, 消化管組織で合成された $\mathrm{Le}^{\mathrm{a}}, \mathrm{Le}^{\mathrm{b}}$ 抗原エピ トープをもつ糖脂質が血槳から赤血球表面に吸着 した抗原である ${ }^{8 \sim 12)}$. したがって, 症例 4 が BMT 後もドナー型に変換されないのは, 消化管組織で 産生された抗原が赤血球表面に吸着したためと考 えられる。

BMT 長期間経過後, ABO 式血液型でも, Lewis 式血液型と同様な機構が存在するか否かを確 認するため, 抗体吸着解離試験, PCR-SSP 法を用 いて $\mathrm{ABH}$ 血液型物質の存在を検討した. 今回用 いた抗体吸着解離試験, $\mathrm{B}, \mathrm{A}, \mathrm{O}$ 遺伝子を別々に
増幅する PCR-SSP 法は感度が高く，人工的に作 製した $\mathrm{ABO}$ キメラ検体を用いての検討では，と もに千分の一の微量 $\mathrm{ABO}$ キメラが測定可能であ ると報告されている ${ }^{6) 13)}$. 4 症例とも, $\mathrm{BMT}$ 前の レシピエント型の A または B 血液型物質が微量 存在していることが, 抗体吸着解離試験により観

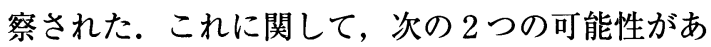
る.（1）移植後も長期間に渡りレシピエントの赤 血球が残存し，キメラを形成した。（2）移植後も レシピエントの非血液細胞から血液型物質が産生 され，ドナー由来の赤血球表面に吸着した。

（1）については, van Leeuwen ら ${ }^{14)} は, B M T$ 後の末梢血または骨髄細胞を cell sorter を用いて ソーティングし，レシピエントの細胞の有無を検 查したところ，ドナーとレシピエントの混合キメ ラを呈する場合があることを報告した，最近，古 川ら ${ }^{15)}$ はマイクロサテライト DNA いて解析し, 34 例中 14 例で造血幹細胞移植後 1 カ月以上経過してもレシピエントの細胞が存在す ることを報告した. BMT 後の混合キメラには, 一 過性に T 細胞においてのみレシピエントの細胞 が検出される状態（transient mixed T-lymphoid chemerism）と，1 年以上に渡って multi-lineage の造血幹細胞にレシピエント細胞が検出される (stable mixed chimerism) の 2 種類が知られてい 
る ${ }^{1416) 17)}$. 古川らの例では, 混合キメラを呈した 14 例はすべて 6 カ月を越えた時点でドナー型の完全 キメラに変化した ${ }^{15)}$. 従って, BMT 後に transient mixed T-lymphoid chemirism を呈する例は 少なくないものの, stable mixed chimerism を呈 する例は多くないと考えられる. BMT 後に混合 キメラを形成しやすい条件として，移植前処置の 軽滅や T 細胞を除去した BMT が知られている.

（2）については, $A B H$ 血液型物質は赤血球以外 に消化管組織, 各分泌液中, 各種蔵器にも存在す ることが知られている ${ }^{12) 181}$. ABH 血液型物質に重 要な $\mathrm{H}$ 物質は, 第 19 染色体上の $\mathrm{H}$ 遺伝子と $\mathrm{Se}$

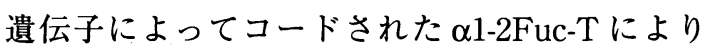
合成される ${ }^{1019)}$. H 酵素は赤血球において $\mathrm{H} 2$ 型 物質 (Fuc $\alpha 1-2$ Gal $\beta 1-4 G l c N A c \beta 1-R)$ を合成し, Se 酵素は消化管組織において H1 型物質 (Fuc $\alpha 1-2$ Gal $\beta 1-3 G l c N A c \beta 1-R)$ を合成する ${ }^{1012)}$. A および B 糖転移酵素が, $\mathrm{H} 1$ と $\mathrm{H} 2$ 型物質に作用して $\mathrm{ABO}$ 式抗原を合成する ${ }^{12200)}$. Dunstan らは， $O$ 型血小 板と $\mathrm{A}$ 型血槳, B 型血槳をそれぞれ反応させ, 抗 体吸着解離試験を行い, 血漿中の $\mathrm{A}$ 型および $\mathrm{B}$ 型の 1 型糖鎖が， $\mathrm{O}$ 型血小板に吸着することを報 告した ${ }^{21}$. 今回検討した 4 症例の Lewis 式血液型 は, Le $(a-b+)$ の分泌型で, 非血液細胞に Se 酵素が存在すると考えられる. 従って, BMT 長期 間経過後, 4 症例の赤血球に認められたレシピエ ント型の $\mathrm{ABH}$ 血液型物質は, 非血液細胞由来の H1 型物質の可能性がある. BMT 後のレシピエン ト末梢血 MNC の ABO 遺伝子型は, 一貫して完 全にドナー型に変化したことは上記の可能性も否 定できない. しかしながら，これらの点に関して はキメラなのか, 吸着なのか, または未発見の機 序によるものか最終的な結論については, 今後, 基礎的検討を行い明らかにする必要がある.

今回の 4 症例において, 糖転移酵素活性は BMT 後もレシピエントの糖転移酵素活性を示し ていた22).この理由として, BMT 後においても, レシピエントの非血液細胞よりレシピエント由来 の糖転移酵素活性の分泌が続くためと考えられ る.しかし, 症例 2 において, BMT 後 97 日, 132 日に 128 倍と糖転移酵素活性を示していたが, 356
日においては活性反応が消失した．この原因とし て, マイナー ABO 不適合 BMTにおいて O 型ド ナーに由来する B リンパ球が, レシピエントの A 型合成酵素に対する抗体を産生したことによる報 告もあり ${ }^{23)}$ 25), その反応による可能性は否定でき ない。一方, $\mathrm{ABO}$ 血液型不適合 $\mathrm{BMT}$ において, $\mathrm{BMT}$ 後のどの時期においてもドナー型の糖転移 酵素活性は認められないとする報告もある ${ }^{26)}$. し かし, 今回の検討では症例 3 と症例 4 において, BMT 後にドナー型の転移酵素活性が確認され た. 症例 1 においては, BMT 後どの時期において もドナー型の糖転移酵素活性は認められなかった が,これは $\mathrm{O}$ 型赤血球の型変換を利用した $\mathrm{A}, \mathrm{B}$ 型合成酵素活性の測定方法のためかもしれない. この方法は定量性にそしく，感度が悪く微弱な酵 素活性を検出し, 型判定することは不可能との報 告もある ${ }^{27)}$.

今回検討した結果は, 症例数が 4 例と少ないた め,さらに多数例を用いて $\mathrm{ABO}$ 血液型不適合 $\mathrm{BMT}$ 後の赤血球を解析する必要がある.

\section{文 献}

1) Yamamoto, F., Clausen, H., White, T., et al. : Molecular genetic basis of the histo-blood group ABO system. Nature, $345: 229-233,1990$.

2) Yamamoto, F., Marken, J., Tsuji, T., et al. : Cloning and characterization of DNA complementary to human UDP-GalNAc : Fuc $\alpha 1 \rightarrow 2$ Gal $\alpha 1 \rightarrow 3$ GalNAc transferase ( histoblood group A transferase) mRNA. J. Biol. Chem., 265 : 1146-1151, 1990.

3) Ogasawara, K., Yabe, R., Uchikawa, M., et al. : Molecular genetic analysis of variant phenotypes of the ABO blood group system. Blood, 88 : 2732-2737, 1996.

4) David, B., Bernard, D., Navenot, JM., et al. : Flow cytometric monitoring of red blood cell chimerism after bone marrow transplantation. Transfus. Med., $9: 209-217,1999$.

5) Schenkel-Brunner, H,Tuppy, H. : Enzymes from human gastric mucosa conferring blood-group A and B specificitiies upon erythrocytes. Eur. J. Biochem., $17: 218-222,1970$.

6）福森泰雄, 大軒子郎, 柴田弘俊, 他：Allele-specific $\mathrm{PCR}$ を用いた $\mathrm{ABO}$ 遺伝子型解析と $\mathrm{ABO}$ キメラ 解析への応用. 日輸血会誌, $40: 1000,1994$. 
7) Landsteiner, K,Miller, C.P. : Serological studies on the blood of primates. The blood groups in anthropoid apes. J. Exp. Med., 42:853-862, 1925.

8) Nishihara, S., Narimatu, H., Iwasaki, H., et al. : Molecular genetic analysis of the human lewis histoblood group system. J. Biol. Chem., 269 : 2927129278, 1994.

9) Clausen, H,Hakomori, S.I. : $\mathrm{ABH}$ and related histo-blood group antigens ; immunochemical differences in carrier isotypes and their distribution. Vox Sang., 56 : 1-20, 1989.

10) Kudo, T., Iwasaki, H., Narimatu, H., et al. : Molecular genetic analysis of the human lewis histoblood group system. J. Biol. Chem., 271 : 98309837, 1996.

11) Anstee, D.J. : Blood group-active surface molecules of the human red blood cell. Vox Sang., 58 : $1-20,1990$.

12) Hakomori, S. : Antigen structure and genetic basis of histo-blood groups $\mathrm{A}, \mathrm{B}$ and $\mathrm{O}$ : their changes associated with human cancer. Biochim. Biophys. Acta, 1473 : 247-266, 1999.

13）山下万利子, 南 裕史, 秋田真哉, 他: ABO 血液 型の遺伝子解析から $\mathrm{ABO}$ キメラと考えられた一 例. 血液事業, 20：185-192, 1997.

14) Van Leeuwen, JE., Van Tol, MJ., Joosten AM., et al. : Persistence of host-type hematopoiesis after allogeneic bone marrow transplantation for leukemia is significantly related to the recipient's age and/or the conditioning regimen, but it is not associated with an increased risk of relapse. Blood, 83(10) : 3059-3067, 1994.

15）古川達雄, 橋本誠雄, 稲野浩一, 他: 造血器悪性 腫瘍に対する同種造血幹細胞移植後の chimerism 解析. 臨床血液, 42 (6) : 488-495, 2001.

16) Ramirez, M., Diaz, MA., Garcia-Sanchez, F., et al. : Chimerism after allogeneic hematopoietic cell transplantation in childhood acute lymphoblastic leukemia. Bone Marrow Transplant. 18 (6) : 1161-1165, 1996.

17) Bader, P., Holle, W., Klingebiel, T., et al. : Mixed hematopoietic chimerism after allogeneic bone marrow transplantation : the impact of quantitative PCR analysis for prediction of relapse and graft rejection in children. Bone Marrow Transplant. 19(7) : $697702,1997$.

18) Zmijewski, C.M. : Immunohematology, 3rd ed., Appleton-Century-Crofts, NewYork, 1978, 72.

19) Oriol, R., Candelier, J.J., Mollicone, R. : Molecular genetics of H. Vox Sang., 78 : 105-108, 2000.

20) Yamamoto, F. : Molecular genetics of ABO. Vox Sang., $78: 91-103,2000$.

21) Dunstan, R.A., Simpson, M.B., Knowles, R.W., et al. : The origin of ABH antigens on human platelets. Blood, $65: 615-619,1985$.

22) Maeda, K., Taniwaki, K., Santo, T., et al. : Anti-A and/or anti-B is not detectable in some patients who underwent $\mathrm{ABO}$-incompatible bone marrow transplantation. Transfusion, $35: 635-639,1995$.

23) Barborra, L., Mojena, M., Bosa, L. : Presence of antibody to A- and B-transferase in minor incompatible bone marrow transplantation. Brit. J. Haemat., $70: 471-476,1988$.

24) Matsue, K., Yasue, S., Matsuda, T., et al. : Plasma glycosyltransferase activity after ABO-incompatible bone marrow transplantation and development of an Inhibitor for glycosyltransferase activity. Exp. Hemat., $17: 827-831,1989$.

25) Kominato, Y., Fujikura, T., Shimada, I., et al. : Monoclonal antibody to blood group glycosyltransferase produced by hybrids constructed with Epstein-Barr-virus-transformed B lymphcytes from a patient with ABO-Incompatible bone marrow transplant and mouse myeloma cells. Vox Sang., $59: 116$-118, 1990.

26) Ikemoto, S., Kajii, E., Tsuchida, S., et al. : Behavior of genetic markers in recipients after bone marrow transplantation and problems in forensic medicine. J. Foren. Sci., 35 : 548-553, 1990.

27) Cartron, J.P., Gerbal, A., Badet, J., et al. : Assay of $\alpha$-N-acetylgalactosaminyltransferases in human sera. Vox Sang., 28 : 347-365, 1975. 